\title{
Ex-citable Accounting and the Development of Pervasive Innovation
}

\author{
Revellino, Silvana ; Mouritsen, Jan
}

Document Version

Accepted author manuscript

Published in:

Qualitative Research in Accounting \& Management

DOI:

10.1108/QRAM-01-2017-0002

Publication date:

2017

License

Unspecified

Citation for published version (APA):

Revellino, S., \& Mouritsen, J. (2017). Ex-citable Accounting and the Development of Pervasive Innovation. Qualitative Research in Accounting \& Management, 14(4), 448-466. https://doi.org/10.1108/QRAM-01-20170002

Link to publication in CBS Research Portal

\section{General rights}

Copyright and moral rights for the publications made accessible in the public portal are retained by the authors and/or other copyright owners and it is a condition of accessing publications that users recognise and abide by the legal requirements associated with these rights.

\section{Take down policy}

If you believe that this document breaches copyright please contact us (research.lib@cbs.dk) providing details, and we will remove access to the work immediately and investigate your claim. 


\title{
Ex-citable Accounting and the Development of Pervasive Innovation
}

\author{
Silvana Revellino and Jan Mouritsen
}

Journal article (Accepted manuscript)

CITE: Ex-citable Accounting and the Development of Pervasive Innovation. / Revellino, Silvana ; Mouritsen, Jan. In: Qualitative Research in Accounting \& Management, Vol. 14, №. 4, २017, p. 448-466.

This article is [? Emerald Group Publishing and permission has been granted for this version to appear here: https://research.cbs.dk/en/publications/ex-citable-accounting-and-the-development-of-pervasiveinnovation. Emerald does not grant permission for this article to be further copied/distributed or hosted elsewhere without the express permission from Emerald Group Publishing Limited.

DOI: 10.1108/QRAM-01-2017-0002

Uploaded to CBS Research Portal: January 2019 


\title{
Ex-citable Accounting and the Development of Pervasive Innovation
}

\author{
Silvana Revellino and Jan Mouritsen
}

To appear in Qualitative Research in Management Accounting

\begin{abstract}
In this paper, we explain accounting's excitable relations with values in and of innovation. Specifically, we draw on Judith Butler's work and her notion of excitability to explain how multiple values may arise when accounting interacts with innovation. Through this lens, accounting can be theorised as an excitable force involved in provoking and transforming innovation and its associated values, notably beyond innovators' initial intentions. Thus, innovation is not a stable object but a pervasive movement diffusing multiple values. In the course of this pervasive process, innovations, which are born to develop private interests, can possibly generate public goods.
\end{abstract}

\section{Introduction}

Through this paper, we aim to explain accounting's excitable interactions with values in and of innovation. Drawing on Judith Butler's work (1993; 1997a; 2010) it is possible to understand how accounting helps provoke innovation and participate in the generation of values by activating processes that pervade categorical spaces. Through Butler's (1997a) concept of excitability it is possible to imagine accounting as a force that engages different values often with multiple and sometimes surprising effects of this engagement. This theoretical lens reinvigorates the philosophical dimensions of qualitative research on management accounting (Burns, 2014; de Loo \& Lowe, 2011), and it helps explaining how accounting provokes the world; particularly how it engages issues around innovation. It is in a relationship between accounting and the world that it is possible to benefit from the advantages of using this theoretical lens because here are tensions which, can also, despite the 
intensions, open 'performable spaces' from where creativity and innovative processes can grow (Busco \& Quattrone, 2015, 2017; Busco, Quattrone, \& Riccaboni, 2007).

This paper adds a layer to previous performativity studies which conceptualise accounting as a structure of wanting and desire which enacts the performable spaces of innovation (Busco \& Quattrone, 2015, 2017; Busco, Quattrone, \& Riccaboni, 2007), by showing that it is also because of accounting properties, such as ex-citability, that the performing of ties between accounting structures and innovation are made possible. Ex-citability happens because accounting is a set of citations of the world that produce ex-citability when they circulate away from its original production. Thus, the study opens reflection on some of the complexities and nuances of this performing processes shedding lights on the multiplicity and variability of values which are generated.

Management accounting literature that dealt with the role of management control systems in enacting innovation has primarily engaged the theme of economic value (Davila et al., 2006; 2007). Yet, the variability of the values produced by innovation has been indicated by the literature on social innovation (Phills Jr. et al., 2008; Mumford, 2002; Mumford and Moertl, 2003; Becattini, 2004; Grimm et al. 2013; Seyfang and Smith 2007; Scott-Cato and Hillier 2010) which, by using the label 'social' separates between business and social values. It is fruitful to note that innovation, may not be understood categorically, rather it may be theorised as a process of becoming that creates surprises about not only the trajectory of the innovation (Revellino and Mouritsen, 2015), but also about the construction of value(s).

We illustrate this point by considering a technological innovation - the Telepass, an automatic toll-collection device used on motorways to move traffic smoothly, fast and safely. The Telepass was developed at the end of the 1980s by Autostrade, an Italian company, which (thanks to this innovation) became a leader in not only the production and the optimisation of solutions for electronic toll collection (ETC) but also infomobility, vehicle monitoring and tracking systems.

Telepass was initially an innovation designed to economise costs and legitimise the company as a governmental licensee for the collection of toll collection fees. Surprisingly, it turned out to be an instrument that, through further attachments, spread values through society and produced public goods, such as safety, mobility, legality and environmental preservation. 
In this paper, by mobilising Butler's performativity theory, we focus on how this technology develops different values. We introduce the notion of pervasiveness to refer to the way that an innovation produces multiple effects and generates multiple values. This concept theoretically, practically and descriptively seems more interesting than the dualism of business/social innovation. The word pervasiveness (from the Latin pervadere, derived from vadere [to go] and per [through]) in the sense of 'going through', pays attention to how social ties are extended, enacted and mediated. It stands for values that are not stable but move in different directions.

From Butler's performativity perspective, the Telepass innovation story is sensitive to the capitalisation on its effects. It focuses on emergence through flows of action made possible by the interaction between the innovation and the knowledge about its effects as capitalised by calculative instruments.

Qualitative research in accounting may benefit from this theory because it gives a more central role to the calculative instruments of accounting in models of innovation as accounting can provoke new patterns of uses, wants and experiences. This philosophical perspective can reorient the study of the management control technologies for innovation into forms that do not aspire to be true or false. They are simply considered complex, ongoing, always incomplete acts and as such, performative. A performative conception of value may reshape our understanding of the production of what is normally categorised as business versus social innovation.

Autostrade's Telepass is a good example of a pervasive innovation. By creating unprecedented applications, it gives rise to values that are social, not because they are unrelated to business values but because pervasive linkages extend this innovation into spaces other than those originally forecasted. Values are relational forces that need connections to come to life. Values are not absolute terms; they do not have stable characteristics and do not exist in isolation but evolve when linkages multiply. Values are never conclusively defined and the innovation enacted by accounting calculations is not a stable object embracing only one dimension of value. It can happen that innovations, which are born to defend private interests, can generate public goods.

\section{Philosophical underpinning of Butler's performativity theory}

Borrowed from the philosophy of language, performativity is a term characterising elements, such as accounting, that do not just represent the world but help to realise it, make it up and provoke it. The 
capacity to influence and constitute the world rather than only describe and represent it has been first theorised by the philosopher of language J. Austin (1962). In his theory of speech acts he explains the capacity of language to put things into being and questions the weakness of the representationalism underpinning logical positivism, which maintains that the only role of language is to represent reality by means of verifiable statements. By regarding language as performative, Austin suggests its potential to do something to the world rather than merely depicting an already existing state of affairs (such as in the constative statement "It is raining"). In How to do things with words, Austin (1962) fosters the illocutionary aspect of language that tends to consider any utterance as an entity that brings into action itself and, by doing so, it becomes a thing done: to inaugurate a situation, give rise to an event, make an agreement that produces irreversible effects in the current state of affairs. According to the illocutionary idea of performativity, communication is always, immediately, a creation of identity and reality.

As noticed by Derrida (1977) in the essay Signature, event, context, Austin, despite his attempt to subvert the foundations of the traditional linguistics, did not escape from the seduction of the paradigm of the so-called "sovereign subject" which has attracted most part of the Western philosophical thought. The claim of the sovereign subject is that the effects of his actions will be similar to his intentions. The underlying theoretical assumption is the minimization of the distance between emotions and will, will and speech, the latter and acts.

The American philosopher Judith Butler (1993, 1997a, 1997b), drawing on Derrida 's critique of Austin's speech act theory, rethinks the notion of the performative utterance from the vantage point of perlocutionary action (in this direction, see also the contributions of Campbell, 1973; Cohen, 1973; Davis, 1979; Gaines, 1979; Gu, 1993). Butler (1993, 1997a, 1997b) maintains that the perlocutionary character of the speech act, whose consequences on the world are not the expected ones, is the most interesting dimension to focus on. Boosting the perlocutionary aspect of language, implies to emphasize the non-coincidence between words, meant as "means" to do things, and things done. This is a particularly promising perspective for analysing innovation.

In the performative utterance, Butler recognizes a type of communication that does not consist in the mimetic transfer of an already given meaning - a meaning belonging to the essence of the thing and which is expressed through the signs of language - but that by itself constitutes an innovation, the creative production of something that was not there before. According to Butler, attributing to language a capacity of doing means accepting the idea that in the relationship between the written or 
verbal utterance (the sign) - guided or not by the intention to do a certain thing - and the consequences of that utterance there is an ineradicable tension. The relevant thing here is not the intention but the fact that the utterance and its consequence are in tension; i.e., in a state of continuous mismatching. Butler observes:

"The main concerns of Excitable Speech are both rhetorical and political. In the law, 'excitable' utterances are those made under duress, usually confessions that cannot be used in court because they do not reflect the balanced mental state of the utterer. My presumption is that speech is always in some ways out of our control. (Butler, 1997, p. p. 15)

Excitable speech reveals, then, a disconnection between the intentions surrounding the utterance and the produced effects. The speech of someone speaking under coercion offers an example of this disconnection. The speech act is as unconnected from the speaker to the point that it cannot be used in a court. This tension between citations spreading by signs and actions creates a sort of ex-citable movement, which goes from representations to re-presentations. Ex-citability is, as such, this movement, which goes beyond the cited sign producing also surprising effects. Ex-citability transforms any citation into a re-citation (a new citation) because it constitutes a space whose contours are not stable. In this escaping from fixity, any re-presentation is typically a betrayal of the original representation.

Precisely the peculiar case of coercion is remembered by John Austin as a "misfire", a sort of infelicitous condition that can affect performative utterances:

“...actions in general (not all) are liable, for example, to be done under duress, or by accident, or owing to this or that variety of mistake, say, or otherwise unintentionally. In many such cases we are certainly unwilling to say of some such act simply that it was done or that he did it." (Austin, 1962, p. 21)

Speaking under duress, blackmail, or on behalf of someone else are confined by Austin among the "non-ordinary" usages of language since "the total situation in which the utterance is issued-the total speech-act" (Ibid. p. 52) escapes from the speaker's control.

Butler, contrary to Austin, suggests that all speech is in some way excitable and, as such, it may thus "exceed the moment it occasions" (1997a: 14) and escapes from the speaker's control. When she 
claims that all speech is ex-citable, this implies that the utterer is not alone in the creation of his words:

"the one who acts (who is not the same as the sovereign subject) acts precisely to the extent that he or she is constituted as an actor and, hence, operating within a linguistic field of enabling constraints from the outset" (Butler, 1997a: 16).

According to Butler the strength of a performative utterance should be sought when the bond between the utterer and the context of emission and reception is cut off. Among the options, which Austin discards as 'misfire', it is possible to find the cue for separating the speech act from the utterer. This possibility establishes an alternative notion of agency and then an alternative notion of responsibility.

Butler notes that every linguistic manifestation always materialises itself in some contexts, although this does not necessarily have to be in a unified form and accepted by all. Although linguistic enunciations can be understood as "written signs", the structure of which is recognized precisely in dependence on "spacing". There is a history to the citation.

As Butler writes:

"If a performative provisionally succeeds (and I will suggest that "success" is always and only provisional), then it is not because an intention successfully governs the action of speech, but only because that action echoes prior actions, and accumulates the force of authority through the repetition or citation of a prior and authoritative set of practices (1997a: 51).”

A performative succeeds through history; it gains strength from previous actions; it needs a "citational chain" (Butler, 1993: 282) i.e., the echoes of citations which produce change when circulating. The accumulation, which Butler refers to, resembles capitalization more than arithmetic addition, where it is possible to distinguish, circumscribe and separate the singular and where the sum is exactly equal to the gathering of all the singularities entering the composition. In Butler's view, there is no possibility of delimiting a "single, self-contained moment of performance" (Lois McNay, 1999: 179) because any utterance spreads its effects near and far in time and space. Butler (1997a: 4) expresses it in this way: 
[...] it is not enough to find the appropriate context for the speech act in question, in order to know how best to judge its effects. The speech situation is thus not a simple sort of context, one that might be defined easily by spatial and temporal boundaries. To be injured by speech is to suffer a loss of context, that is, not to know where you are. Indeed, it may be that what is unanticipated about the injurious speech act is what constitutes its injury, the sense of putting its addressee out of control. The capacity to circumscribe the situation of the speech act is jeopardised at the moment of injurious address. To be addressed injuriously is not only to be open for an unknown future, but not to know the time and place of injury, and to suffer the disorientation of one's situation as the effect of such speech [...].

The impossibility of judging the unknown and unintended effects makes Austin's distinction between illocutionary and perlocutionary acts difficult. The implication is that performativity becomes a way "to supply an alternative to causal frameworks for thinking about effects" (Butler, 2010: 147). As Butler (2010) suggests, there is always a perlocutionary underpinning that fuels the illocutionary force of performative acts. An illocutionary speech act may enact its effects at the moment of utterance, but its illocutionary force is derived from "the accumulating and dissimulating historicity of force" (Butler, 1993: 227, 1997a: 51).

In Excitable Speech, Butler (1997a) makes the point that speech acts are always beyond their speakers' control (or even comprehension); in this sense, they are "excitable". Perlocutionary utterances need a network to come to life. No autonomous agent can produce them alone because there is always a rupture in the chain of causality between subject and act, which makes subjects not uniquely accountable for their speech. The possibility for agency and "resignification", which is contained in what Butler (1997a: 15) calls "the open temporality of the speech act", creates a distance between an utterance and its effects. This idea leads Butler to sustain the non-sovereignty of agents in language, whose characteristic is that of a citational chain preceding and exceeding speaking subjects.

Citations are forms we take from the world and that are reproduced through the force of signs. As signs, they have the power to be cited and re-cited producing change when they are iterated from a citation to another one and become then ex-citable. The iterability of the sign, i.e. its possibility to be cited and re-cited again and again, affirms the precariousness of a performative and its ability to reembody itself into contradictory and subversive versions respect to the stated purposes. 
Similarly, accounting is a type of citation because it can reproduce spheres of the world through the force of signs. As a language based on signs, it is ex-citable because it can produce effects beyond the citational power of the sign. These effects can travel beyond the intentions and the control of the calculative mind. However, excitable accounting does not act alone: excitability provokes the mobilisation of a network of ties, and the kind of perlocutionary chains of action, which it produces, creates the possibility for change and innovation.

\section{Uses of performativity lens in accounting and management studies}

Performativity theories, in their various conceptualizations subtending different ontological and epistemological assumptions (Drost et al., 2017), have gained considerable attention in social sciences and humanities over the past decades. Overall, the notion of performativity has been applied to a wide variety of academic concerns and intellectual traditions (Muniesa, 2010). By examining how theories shape practices, the performativity position has informed the anthropology of markets (Callon, 1998, 2007), the social studies of finance (MacKenzie, 2003a, 2003b, 2004, 2006, 2007, 2009; MacKenzie \& Millo, 2003, 2009; Millo et al., 2005), marketing studies (Kjellberg \& Helgesson, 2006, 2010; Venter et al., 2015) and organisational and management studies (e.g., Beunza \& Stark, 2004; Cabantous \& Gond, 2011; Cabantous, Gond, \& Johnson-Cramer, 2010; D’Adderio \& Pollock, 2014; Ferraro, Pfeffer, \& Sutton, 2005). In the field of science studies (Callon, 1998, 2007, 2010; Latour, 1996, 2005; Muniesa \& Callon, 2007; Muniesa 2014), the performativity concept is mobilised to capture a form of knowledge that (rather than being only descriptive) contributes to the establishment of actions and brings things into being. ${ }^{1}$ When knowledge generated by calculative instruments is assembled "in a particular site, through particular trials, and for a particular audience" (Muniesa \& Callon, 2007, p. 184), then the conditions for inspiring certain things to happen are produced and become the ontological effects of their performativity.

In recent sociological studies of markets, especially financial markets, researchers have argued that economics is performative. MacKenzie (2007) and MacKenzie and Millo (2003) assert that the BlackScholes-Merton model of option pricing became the dominant model used by traders on the Chicago Board Options Exchange in the 1970s, not because it was better at predicting price patterns (in fact, it performed worse than some models) but because its ease of use and incorporation into socio-

\footnotetext{
${ }^{1}$ In Callon's words, "economics [...] performs, shapes and formats the economy, rather than observing how it functions" (1998: 2).
} 
material devices changed the traders' behaviour to fit the theory, which consequently altered price patterns so that they began to resemble the model more closely. However, the way that economics contributes to the creation of markets seems different if we compare, for instance, the works of MacKenzie (2007) and MacKenzie and Millo (2003) with those of Callon (1998), Latour (2005), MacKenzie (2009), MacKenzie and Millo (2009) and Millo et al. (2005). In the first case, the word "performative" is more about adherence to pre-established intentions. In the latter case, the focus is more on the surprising effects and the unexpected consequences produced by economics.

Callon (1998) has pioneered the performative role of accounting and calculative instruments (intended as the body of formal models and techniques that makes economics an analytical endeavour) in shaping the economy. This paper advances the idea that, by enacting calculative agencies, the calculative instruments of accounting perform ties that also influence innovation and its connected values. In order to analyse phenomena, such as accounting's excitable relations with value of innovation, Butler (1993, 1997a, 2010) theory of performativity seems particularly promising.

\section{Excitable accounting and development of pervasive innovation}

When we discuss accounting, we refer to a wide variety of actual and potential calculative instruments (Miller, 1998) that not only describe the world but more importantly, influence it by making it desirable for intervention. This is also the case for the part of the world that is concerned with innovation and where calculative instruments thus assist simultaneously in shaping innovative spaces and people's interest in these spaces.

Stating that the calculative instruments of accounting influence the world or constitute reality involves understanding how accounting is an excitable (from the Latin $e x$ - [prefix particle that adds strength] and citare [move or push out]) technique, that is, how it boosts and enacts levers for engaging with uncertainty, surprises and transformations.

Calculative instruments contribute to changing reality. They concur to produce a multifaceted and evolving reality that cannot be captured in stable entities or wrapped up in bounded definitions (such as the distinction between business and social innovation) because processes are always ongoing, and agencies that are capitalised as experiences are never ending. Considering innovation a performative achievement implies taking into account the problematic conditions that make it work and the 
different shapes that it can take over time and for different actors. This adds to the study of innovation because in this view, the strict separation between innovation that produces public or social value and innovation that produces business or economic value (advanced by some studies) becomes difficult to conceptualise as solid, and this categorisation appears devoid of practical and organisational relevance.

The performativity theory offers a lens for understanding how reality comes into being and is constituted. For this reason, it offers interesting propositions for understanding those phenomena, such as innovation, that move forward, transform things and create new attachments. Gaining awareness of this constitutive power of accounting suggested by performativity means going beyond the "bean counting" (Carruthers, 1995) idea that regards accounting only as a functional technique used to implement paths of action that have been decided elsewhere. Advancing further than the bean counting idea involves recognising the role of accounting in creative and innovative processes as well (Revellino \& Mouritsen, 2009, 2015). This relation is particularly interesting in public sector organisations or in organisations delivering public services, which are often developed via innovation. It then becomes important to understand the possibilities that accounting can play out in these complex endeavours.

\section{Methodology}

The predominant data collection method used in this case study was interviews. The focus was on senior and young professionals who, to a certain extent, played a significant role in the development and the management of innovation and who are still involved in this process. The data were corroborated by participant observation and by the analysis of formal documents.

The systematic observation, recording, description, analysis and interpretation of people's behaviour were facilitated by a working space with a network personal computer (PC) that the company provided. This arrangement eased the preparation of the interviews and made it possible to consult the company's intranet. One of the researchers participated as an observer in a series of meetings and internal seminars, including the annual meeting between the top managers and the middle managers, where the company's achieved objectives were interpreted and commented on and future strategies were addressed. The orientation toward data collection and analysis was exploratory. The aim was to generate insights into the practices engaged in the design and diffusion of Telepass and to acquire knowledge of the constellation of effects produced by the unfolding of this innovation. We wanted to 
explore the relationships between the calculative instruments of accounting, the process of the production of innovation and the value(s) that this process of production generated. Data collection and analysis proceeded iteratively. This allowed for some flexibility in data collection, permitting themes to emerge and to be examined more deeply.

Butler (1993, 1997a, 2010) performativity approach (compared to other approaches) seems particularly promising when analysing innovation, where planning works less than change and possible disconnections between intensions and effects may generate serendipitous surprises. In addition to that, this approach offers lenses for exploring the shifting margins of accounting (Miller, 1998), not limiting the exploration solely to what actors historically understood accounting to be but open for the possibility to consider part of an accounting infrastructure not only calculations which have financial implications but other form of quantifications which have the same citational properties of what traditionally is understood accounting to be.

\section{Ex-citable accounting and the performation of pervasive values}

In Italy in the 1980s, the long queues at tollbooths (due to the manual toll-collection system) caused protests and popular mobilisations, threatening and questioning the very existence of Autostrade, the company that (based on a governmental agreement) collected tolls on the main Italian motorway network. Some political parties proposed changing the toll-collection system by no longer binding it to the kilometres travelled by motorists but introducing a fixed annual fee through putting a sticker on the car windscreen. These pressures led Autostrade to look for a solution that would eliminate queues at tollbooths while guaranteeing the company's profitability. The search for economic value was a force that let people search for a solution. Autostrade's solution, the Telepass, was a revolutionary innovation at that time, as noted by the company's CTO (Chief Technology Officer):

Telepass now seems an obvious wheeze, but at the time it was a revolutionary innovation. It had to deal with the fragmented motorway network in about twenty different companies, with the hostility of the unions which were concerned about the loss of jobs and the complexity of an IT system that was supposed to connect the centre and the periphery when the Internet was not yet working.

Telepass enabled the dynamic toll collection by using the dedicated short-range communication 
(DSRC) microwave technology on the 5.8-Ghz frequency for communication between the on-board vehicle equipment and track infrastructures. Each Telepass gate was equipped with devices that permitted the automatic management of transits. Each motorist had an on-board terminal, which connected with the information systems for charging the transit to the customer's bank account. Through Telepass, toll payment at each tollbooth's exit gate occurred in 50 milliseconds, according to the phases shown in Figure 1. When a vehicle equipped with the on-board device passed through the track and the antenna placed on the track recognised the on-board device, a unique identification code was transmitted, and the control unit on the track station recorded the passage and gave the order to raise the beam. Meanwhile, by noting the car's entry and exit, the gate calculated the account of the toll fee based on the kilometres driven and the type of vehicle. This information was sent to the data centre that matched the code of the Telepass apparatus with the contract holder and debited his or her bank account.

Telepass was not only a technology for paying toll fees and increasing the company's profitability by enhancing the motorway's capacity utilization. It was also an information-collection device that monitored motorists' behaviour. At the beginning this information was a side product of the transfer of money for the passage on the road. However, it turned out to be more of a backbone of an increasingly information-rich, big-data operation that acted back on the motorists' behaviour. In this sense, Telepass became performative. It became a key element in an expanding network of devices and sensors that would increase the intensity of influencing and monitoring motorists' behaviour. Telepass made Autostrade a forerunner in the development of technologies for ETC (Electronic Toll Collection) and set the foundations for the subsequent evolution of toll systems based on satellite technology without barriers. These so called "free-flow multilane" portals were placed along the motorway before each junction. The free-flow system, which allowed the payment of tolls without slowing down and without channelling, combined two technologies - microwave radio systems with DSRC technology (Telepass antennas) and cameras for recognising plate numbers. Figure 2 illustrates the development curves of the various devices that since 1990 have been introduced to automate toll collection, first using DSRC and then satellite technology.

Even more importantly, to understand its performativity, Telepass produced of an ecology of calculative instruments based on data and statistics on motoring. This extensive information were citations becoming excitable for developing further innovations increased the quality of the motorway management and impacted on the motorists' driving style and life. Thanks to Telepass' calculative 
infrastructure, Autostrade pioneered the development of systems for managing motorway traffic (integrated viability system [IVS]) and for preventing and reducing road accidents and increasing safety (Tutor).

\section{Integrated viability system}

The IVS assembled and integrated different specialised application modules into a unique architecture (Figure 3). The Tracking Module provided information about vehicles on a georeferenced map. The Traffic Forecast Module visualised traffic forecasts linked to particular events. The Autotraf Module calculated the mean travel times that were necessary to reach destinations along the motorway route. The Weather Portal monitored weather conditions and produced forecasts. The SOS Module registered alarms sent from the SOS columns placed along the motorway route. The Construction Site Module gave information on the work in progress and the work being scheduled on the motorway network. The Exceptional Transport Module displayed information on exceptional transports (abnormal load, hazardous cargo, etc.). The Winter Operations Module managed the entire workflow for cold-weather activities and managed the interfaces with the video screens placed along the motorway.

In the same application, this informational infrastructure made it possible to visualise (see Figure 4) single signals (only vehicle tracking, only cameras, only sensors, etc.) and groups of signals or all signal categories simultaneously at a certain point in time and over time. This information produced a global view of traffic events, weather, fleet vehicles, tracking and traffic conditions, as well as other important data from every module. The operation of Autotraf, one of the modules of the IVS, produced information through calculations of signals from Telepass and its associated systems of sensors. This function made it possible to develop calculations about travel time which, when published, would influence motorists' behaviour; thus, the motorways' capacity would be used in different ways. Such information would be performative because it would provoke people to make new choices. The more expanded the information was set, the more choices would be possible. The whole range of functions performed by the IVS would extend the possibilities for motorists to consider both the motorway's capacity and the events that would impose barriers to the fluidity of the traffic. The IVS became an advanced calculative apparatus and data analysis platform that, by combining artificial and analytical intelligence, produced knowledge that would affect key values, such as the motorway's fluidity and safety. This was a key performative moment. By capitalising on the data produced by motorists when driving on the motorway, Telepass was able to accumulate 
patterns of traces about their behaviour. These patterns of traces gradually found their way into new calculative devices, making it possible to envisage the motorway's uses in new ways. These new calculative devices were assembled into what Autostrade called the IVS. Motorists in a click could get real time information on traffic fluidity and possible obstacles. By selecting the departure point and the arrival destination of their journey, they get information on the time necessary to reach a destination (see fig. 5a).

Figure $5 \mathrm{a}$, together with figure $5 \mathrm{~b}$ and $5 \mathrm{c}$, shows how ex-citability works; what does it mean for a citation that it can become ex-citable? What are the relations between citation and ex-citability? Citations are not predictions. When motorists obtain information, how do things ex-cite? How they make choices? It is hard to imagine that these pictures are deterministic, rather they engage somehow the motorists, they excite the way motorists think their strategy. Motorists do not just respond, they do something with them: they look at the pictures, they may rethink their options and opportunities, they can change and accommodate their travel, make up their view of strategy and value.

These pictures do not tell us what happens when motorists look at queues, also because this process does not end up to one result only. The materialization of these manifestations in real contexts does not happen in a unified form or it is accepted by all at the same way, although these citations can be understood when manifested in signs.

The types of citations that motorists face do not require translation, they require excitability because motorists have to be moved in new contexts. They need to speculate on other things, on their commitments, they may have to change the time of their meetings, etc. Motorists' decisions come true through some sort of interpretations when they need to change their mobility strategy.

It is not a simple cause-effect but it requires motorists to think about different types of values when they making decisions. This is ex-citement. In this sense it is not a simple cause-effect between the citation and the ex-citement but there is a chance that motorists will reconsider when to move, how to move and perhaps even change obligations, destination. Citations do not produce certainty. The queues depend also on the strategies of other motorists: if everybody postpones their trip, the queue will be postponed too. This is not a prediction, a positivist thing, it is an excitement because it creates in motorists a concern and a new strategy has to be made: a link with history in a new way.

These different modules helped transform driving behaviour. Via the accumulation of data from 
Telepass and its increasing set of sister technologies, visual displays made motorists more responsible drivers. Not only did Telepass enable payments, it also gave feedback to motorists and impacted the way that they travelled by encouraging them to drive where there was most unused space on the motorway and making them interested in saving time and fuel. The calculative instruments expanded information; by being disclosed, they also affected the motorists' organisation of their journeys. All these in turn influenced the motorway's productivity. Performativity is this pervasive movement that proceeds from one stage to another when new information excites the development of even further technologies for provoking and making things real.

\title{
Improving road safety: the Tutor
}

Telepass' technology and the calculations it permitted also were the forerunner of another innovation: the Tutor, a technological artefact aimed at improving road safety. This system measured the average vehicle speed and enabled automatic fining of speed-limit violations without requiring a police officer's presence on the road. To control the average vehicle speed, Tutor worked on two peripheral monitoring points that detected the vehicle data (speed, class and license plate). This information was sent to a central server that collected it and certified its origin and the absence of alterations.

The Tutor system worked as a preventive tool, capable of influencing driving behaviours:

\begin{abstract}
"Statistics show that over $90 \%$ of fatal accidents are caused by bad driving behaviour and that approximately $60 \%$ of the deaths occurring on the highway every year are speedrelated. The initiative aims to prevent road traffic accidents by educating motorists, through information, to reduce speed and respect the speed limits. Those travelling on the highway are invited to drive prudently along the entire network and not only in proximity of speed cameras." (source: Autostrade website http://www.autostrade.it/en/controllodella-velocita/tutor)
\end{abstract}

Its use had drastically and progressively reduced the peak and the average vehicle speeds. The Tutor system also brought about a sharp decrease in accident rates. During its first 12 months of operation, this system led to a significant reduction in the average vehicle speed (-15\%) and the peak speed ($25 \%$ ), which also resulted in a net reduction of the accident rate and its consequences for people (mortality rate: $-51 \%$, rate of accidents with injuries: $-27 \%$ and accident rate: $-19 \%$ ). Figure 6 shows the decrease of the death rate on the Autostrade's motorway network during the period 2000-2016. 
The lives saved was another value brought about by technology through the ex-citability of accounting.

Tutor created new connections between the police and motorists. It also motivated motorists to engage in establishing not only safety but also legality since, by further attachments, this innovation entered the systems for controlling access in urban areas (restricted traffic zones or zona a traffico limitato $[Z T L]$ in Italian) and supported police procedures for ascertaining violations and issuing fines.

In addition to activating motorists in boosting the effectiveness and the efficiency of the police, Tutor produced other types of values which spread outside the company's borders. In fact, by promoting the decrease in the average speed and a more uniform driving style, it concurred, caeteris paribus, to reduce carbon dioxide emissions. Overall, the Telepass innovation was designed with the view of preserving the Autostrade company's private interests and benefits. However, it also developed public goods, such as safety, traffic fluidity, reduced time taken to travel from one point to another on the motorway and conversely, the time saved by avoiding queues, and freedom of movement. All these are sort of public goods, which generate diffused values (quality of life, safety, legality and environmental preservation).

Telepass performed beyond the space of toll-collection processes. Its perlocutionary force produced effects in many directions. Motorists saved time during trips. Queues were reduced at the tollbooths. Autostrade economised its investments in the motorway tarmac and reinforced its position as a licensee of a public service, such as mobility, by the Italian government.

The performative force of the calculations on transits developed through Telepass had wide-ranging effects and they also extended the space of this innovation. They created new alliances, possibilities, horizons and forces for boosting innovation. In this sense, they were excitable. In these movements, different values were produced beyond the economic value. However, this expansion of values came from the same source. This is pervasiveness.

\section{Pervasiveness: performative movement that shapes multiple values}

The story of the Telepass innovation, created by Autostrade, illustrates what is gained when innovation is understood as pervasive. The notion of pervasiveness depicts an innovation that is able to extend and change its boundaries and linkages in unpredictable ways as well. These performative 
movements happen especially when there is a temporal disconnection between actions and consequences.

The notion of pervasiveness can problematise the division between business and social values, and can thus be used for the analysis of the dynamic of values. Values can be imagined $a b$ origine, but they may not be contractible to a plan. Telepass turned out to be a technology for accumulating information (or citations) that was progressively put together and capitalised on, alongside the pervasive values of its deployment on Autostrade and Italian society. Telepass illustrates that it is only possible to create productions - to assemble things - in ongoing processes, and the values produced in such movements are always evolving and multiple. However, for this reason, they are always social.

This analysis adds to the previous literature about the relationships between accounting instruments and innovation, which has focused on uncertainty, creativity and new product development (e.g., Ahrens \& Chapman, 2004; Bisbe \& Otley, 2004; Brown \& Eisenhardt, 1997; Cardinal, 2001; Chapman, 1998; Davila, 2000; Davila et al., 2009a, 2009b; Ditillo, 2004; Hansen \& Jönsson, 2005; Ittner \& Kogut, 1995; Jørgensen \& Messner, 2009, 2010; Zirger \& Maidique, 1990). The literature has claimed that formal management control systems support innovative courses of action, where they are implemented in an enabling (Ahrens \& Chapman, 2004; Widener, 2007) or an interactive way (Bisbe \& Malagueno, 2009; Bisbe \& Otley, 2004; Simons, 1995). The study of Telepass adds a dynamic dimension to this. Uncertainty is not only a condition but is also produced by the effects of calculative instruments, which impose themselves on motorists. Innovation is not located in a mind but in a whole constellation of relations among motorway technologies, motorway infrastructures, calculative devices and users who take these into account. It is distributed. Moreover, new product development may not only be a project but also a process where one 'product' leads the way to another. The product development process is extended by the calculative potentialities produced by technologies. As more information is constantly collected, the calculative challenge increases. This is performativity - things happen in surprising ways over time but always with a connection to the past and the future.

Pervasiveness can explain how innovation develops different values through social interactions, and by enrolling sceptical resource providers through such ties, it is able to create, extend and reinforce linkages to other resources. As a process of unfolding ties binding heterogeneous elements, pervasiveness can explain how the calculative instruments participate in shaping innovations (Akrich, 
1992). The idea of pervasiveness as going through explains why the social character of innovation does not reside in a particular feature of the innovative object but in the ties, which hold together the combination of resources that mobilise courses of innovative action. The relational character of such movements, generated by the pervasiveness of the ties, invites perceiving innovation as a process that contains its history and possible futures, as well as a relation that gathers its ties to other relations as part of itself.

\section{Conclusion}

This paper is about the relationship between knowledge of the world through accounting references (citations) and the formation of the world. Particularly, we have attempted to explain the accounting's excitable interaction with innovation as seen through Judith Butler's perlocutionary view of performativity. Overall performativity lies in how things unfold in the world. The use of Butler notion of performativity supports a movement from a representationalist to a re-presentationalist version of accounting information where accounting references, or citations, can be seen as an excitable force which produce effects even beyond the intentions and the control of actors. Excitability is the property of accounting, as a language articulated on a system of references, to induce stimuli, actions and reactions which are able to change the world.

This theoretical lens helps to understand how the calculative instruments of accounting and innovation co-develop dynamically and participate in the generation of values, which can hardly be categorised as only a singular social or business value. We have shown how the innovation enacted by accounting calculations is not a stable object but a project that develops even beyond the originally forecasted object. When these pervasive movements unfold, innovations designed for defending private interests can possibly generate public goods. Butler's notion of performativity makes it possible to realise how change in value(s) requires a word different to the simple separation between social and economic value in order to characterise their dynamic evolution. Value(s) generated in the relationships between accounting and innovation technology evolve when a system of references, such as accounting, acts upon innovation and let this travel through spaces wider than those originally imagined. A value is pervasive because it links different evaluable domains. A pervasive value is never stable, similarly to the Butlerian perlocutionary utterances, it encompasses the context of its 
instantiation and travels through a "nexus of temporal horizons" (Butler, 1997a: 14) where past, present and even future unforeseen elements participate in its dynamic composition.

Through the performativity lens, accounting becomes an excitable force. Such a force lustily puts in motion processes of becoming, while innovation becomes a pervasive movement that extends its effects and enters value spaces other than those originally forecasted. Performativity provides the possibility to analyse the variability of values. It does not label a value through a specific tag because values are evolving, and due to their mutable character, they are social.

\section{References}

Ahrens T. and Chapman C. S. (2004) Accounting for flexibility and efficiency: A field study of management control systems in a restaurant chain; Contemporary Accounting Research 21(2): 271-301.

Akrich, M. (1992). 'The description of technical objects' Bijker, W. E., Law, J. (eds) Shaping technology/building society, MIT Press, Cambridge

Austin, J. L. (1962) How to do Things with Words, Harvard University Press, Cambridge, MA.

Becattini G. (2004), Per un capitalismo dal volto umano. Critica dell'economia apolitica, Bollati Boringhieri, Torino.

Beunza, D., and Stark, D. (2004) Tools of the trade: The sociotechnology of arbitrage in a Wall Street trading room. Industrial and Corporate Change, 13, 369-400.

Bisbe J. and Otley D. (2004) The effects of the interactive use of management control systems on product innovation; Accounting, Organizations and Society 29 (8): 709-737.

Bisbe J. and Malagueno P. (2009) The Choice of Interactive Control systems under Different Innovation Management Modes; European Accounting Review 18 (2): 371-415.

Brown, S. L., and Eisenhardt, K. M. 1997. "The art of continuous change: Linking complexity theory and time-paced evolution in relentlessly shifting organizations". Administrative Science Quarterly, 42: 1-34.

Burns J. (2014) Qualitative management accounting research in QRAM: some reflections; Qualitative Research in Accounting \& Management, Vol. 11 Iss 1 pp. $71-81$

Busco, C., \& Quattrone, P. (2015). Exploring How the Balanced Scorecard Engages and Unfolds: Articulating the Visual Power of Accounting Inscriptions. Contemporary Accounting Research, 32(3), 1236-1262.

Busco, C., \& Quattrone, P. (2017). In Search of the "Perfect One": How accounting as a maieutic machine sustains inventions through generative "in-tensions." Management Accounting Research. 
Busco, C., Quattrone, P., \& Riccaboni, A. (2007). Management Accounting. Issues in interpreting its nature and change. Management Accounting Research, 18 (2) 125-149.

Butler, Judith (1993) Bodies That Matter. Routledge, London.

Butler, Judith (1995) "For a Careful Reading”. In: Benhabib, Seyla, Butler, Judith, Cor- nell, Drucilla and Fraser, Nancy Feminist Contentions. A Philosophical Exchange. Routledge, New York, 127-144.

Butler, J. (1997a) Excitable Speech. A Politics of the Performative. Routledge, New York.

Butler, J. (1997b) The Psychic Life of Power: Theories in Subjection, Stanford: Stanford University Press.

Butler J. (2010) Performative Agency; Journal of Cultural Economy, Vol. 3 (2) July 147-161

Cabantous L., Gond J.-P. (2011) Rational Decision Making as a Performative Practice: Explaining Rationality's Éternel Retour. Organization Science 22: 573-586.

Cabantous, L., J.-P. Gond, M. Johnson-Cramer. Decision Theory As Practice: Crafting Rationality In Organization. Organization Studies 31 (2010): 1531-1566.

Callon, M. (1998) "The embeddedness of economic markets in economics", in Callon, M. (Ed.), The Laws of the Markets, Blackwell Publishers/The Sociological Review, Oxford, pp. 1-57.

Callon, Michel (2007): What Does It Mean to Say That Economics is Performative? In: MacKenzie et al. (2007): 344-357.

Callon M. (2010) Performativity, Misfires and Politics, Journal of Cultural Economy 3, 2: 163-69

Campbell P. (1973) A rhetorical view of locutionary, illocutionary and perlocutionary acts. Quarterly Journal of Speech; 59: 284-296

Cardinal L.B. $2001 \quad$ "Technological innovation in the pharmaceutical industry: the use of organizational control in managing research and development". Organization Science, 12(1): 19-36.

Carruthers, B. (1995) Accounting, ambiguity, and the new institutionalism, Accounting, Organizations and Society, 20, pp. 313-328.

Chapman C.S. (1998) Accountants in organizational networks; Accounting, Organizations and Society 23 (8): 737-766

Cohen T. (1973) Illocutions and Perlocutions; Foundations of Language. Vol. 9, No. 4 Mar., pp. 492503

D’Adderio L. and Pollock N. (2014) Performing Modularity: Competing Rules, Performative Struggles and the Effect of Organizational Theories on the Organization; Organization Studies, Vol. 35(12) 1813-1843

Davila, T. (2000) An empirical study on the drivers of management control systems design in new product development, Accounting, Organizations and Society, 25(4/5), pp. 383-409.

Davila, T.; Epstein, M. J.; Shelton, R. D. (2006) Making Innovation Work: How to Manage It, Measure It, and Profit From It; Pearson Education, Inc., pp. 334 
Davila T., Epstein M. J. and Shelton R (2007) The Creative Enterprise: Managing Innovative Organizations and People; Volumes 1-3; Edited by Praeger Perspectives, Westport, CT, USA; vol. 1 pp. 202

Davila, A., Foster, G. and Oyon, D. (2009a) Accounting and control, entrepreneurship and innovation: Venturing into new research opportunities, European Accounting Review, 18(2), pp. 281-311.

Davila, A., Foster, G. and Li, M. (2009b) Reasons for management control systems adoption: Insights from product development systems choice by early-stage entrepreneurial companies, Accounting, Organizations and Society, 34(3-4), pp. 322-347. Deleuze G. (1992) Postscript on the Societies of Control, October, The MIT Press, vol. 59, Winter, pp.3-7. First appeared in L'Autre journal, n. 1 (May 1990)

Davis S. (1979) Perlocutions. In Searle J., Kiefer F. and Bierwisch M. eds., Speech Act Theory and Pragmatics; Dordrecht: Reidel Publishing Company; pp. 37-55

De Loo, I. and Lowe, A. (2011) Mixed methods research: don't - 'just do it'; Qualitative Research in Accounting \& Management, Vol. 8 No. 1, pp. 22-38.

Derrida J. (1977) "Signature Event Context" copyright (C) 1972 by Les Editions de Minuit. English translation by Samuel Weber and Jeffrey Mehlman first published in Glyph I, 1977. Copyright (C) 1977 by the Johns Hopkins University Press and Editions de Minuit.

Ditillo, A. (2004). Dealing with uncertainty in knowledge-intensive firms: The role of management control systems as knowledge integration mechanisms. Accounting, Organizations and Society, 29, 401-421.

Drost, J. S.; Minnaar R. A; Visser M., Vosselman E. (2017) Accounting in public sector organisations: from (p)re-presentation to performativity; IRSPM Conference, Budapest 2017 - Panel G1 'Accounting and Accountability' Constructing society - history, culture, politics and accounting in the public services

Ferraro, F., Pfeffer, J., and Sutton, R. I. (2005). Economics language and assumptions: How theories can become self-fulfilling. Academy of Management Review, 30, 8-24.

Gaines R. (1979) Doing by saying: Towards a theory of perlocution. Quarterly Journal of Speech; 65: 207-217.

Glass M.R. and Rose-Redwood R. (2014) Performativity, Politics, and the Production of Social Space (Routledge Studies in Human Geography) 1st Edition

Grimm R., Fox C., Baines S. and Albertson K. (2013) Social innovation, an answer to contemporary societal challenges? Locating the concept in theory and practice; Innovation: The European Journal of Social Science Research, Vol. 26, No. 4, 436-455

Gu Y. (1993) The impasse of perlocution. Journal of Pragmatics; 20: 405-432

Hansen, A., \& Jönsson, S. (2005). Target costing and coordination-Framing cost information sharing in new product development. In S. Jönsson \& J. Mouritsen (Eds.), Accounting in Scandinavia - The northern lights. Liber and Copenhagen Business School Press.

Ittner, C., \& Kogut, B. (1995). How control systems can support organisation innovation. In E. H. Bowman \& B. M. Kogut (Eds.), Redesigning the firm (pp. 155-180). New York: Oxford University Press. 
Jørgensen B. and Messner M. (2009) Management control in new product development: The dynamics of managing flexibility and efficiency; Journal of Management Accounting Research (21): 99-124

Jørgensen B. and Messner M. (2010) Accounting and strategizing: A case study from new product development; Accounting, Organization and Society (35): 184-204

Kjellberg, H. \& Helgesson, C. F. (2006). Multiple versions of markets: Multiplicity and performativity in market practice. Industrial Marketing Management, 35(7), 83955.

Kjellberg, H., \& Helgesson, C.-F. (2010). Political marketing. Journal of Cultural Economy, 3 (2), 279-297

Latour, B., (1996) Aramis, or the love of technology, Harvard, Harvard University Press

Latour B. (2005). "Reassembling the Social. An Introduction to Actor-Network-Theory". Oxford University Press.

Lloyd, MS (2007) Judith Butler: From Norms to Politics, Polity Press

MacKenzie, D. 2003a. "Long-Term Capital Management and the Sociology of Arbitrage." Economy and Society 32: 349-380.

MacKenzie, D. 2003b. "An Equation and Its Worlds: Bricolage, Exemplars, Disunity and Performativity in Financial Economics." Social Studies of Science 33: 831-868.

MacKenzie, D. 2004. "The Big, Bad Wolf and the Rational Market: Portfolio Insurance, the 1987 Crash and the Performativity of Economics." Economy and Society 33: 303-334.

MacKenzie D. (2006) An Engine, Not a Camera How Financial Models Shape Markets; The MIT Press Cambridge, Massachusetts London; pp.1-377

MacKenzie D. (2007) Is Economics Performative? Option Theory and the Construction of Derivatives Markets In Do Economists make Markets? On the Performativity of Economics Edited by Donald MacKenzie, Fabian Muniesa, and Lucia Siu, PRINCETON UNIVERSITY PRESS pp. 20-53

MacKenzie D. (2009) Material Markets How Economic Agents Are Constructed; Oxford University Press Inc., New York, pp.1-228

MacKenzie, D. and Millo Y. 2003. "Constructing a Market, Performing Theory: The Historical Sociology of a Financial Derivatives Exchange." American Journal of Sociology 109: 107145.

Mackenzie, D., and Millo, Y. (2009) The usefulness of inaccurate models: Towards an understanding of the emergence of financial risk management, Accounting, Organizations and Society (34) : pp.638-653.

McNay L. (1999) Subject and Psycho and Agency: The Work of Judith Butler"; Theory, Culture and Society 16.2; pp. 175-193

Miller, P. (1998) The Margins of Accounting, European Accounting Review, Vol. 7, pp. 605-621.

Millo Y., Muniesa F., Panourgias N.S., Scott S.V. (2005) Organised detachment: Clearinghouse mechanisms in financial markets; Information and Organization 15 (2005) 229-246

Mumford, M.D. (2002), 'Social Innovation: ten cases from Benjamin Franklin', Creativity Research Journal 14:2, 253-66. 
Mumford, M. D., \& Moertl, P. (2003). Cases of Social Innovation: Lessons From Two Innovations in the 20th Century. Creativity Research Journal, 15(2/3), 261.

Muniesa F. (2010), "Cooling down and heating up: a stress test on politics and economics", in Madeleine Akrich, Yannick Barthe, Fabian Muniesa and Philippe Mustar (eds.), Débordements: Mélanges offerts à Michel Callon, Paris, Presses des Mines: 335-341.

Muniesa F. and Callon M., 2007, Economic Experiments and the Construction of Markets, In Do Economists Make Markets? On the Performativity of Economics Edited by Donald MacKenzie, Fabian Muniesa, and Lucia Siu, Priceton University Press pp.163-189

Muniesa F. (2014) The Provoked Economy: Economic Reality and the Performative Turn, Abingdon, Routledge. pp. 160

Phills, J. A., Deiglmeier K. and Miller D. T. (2008) Rediscovering Social Innovation; Stanford Social Innovation Review 6 (4): 34-43.

Revellino, S. and Mouritsen, J. (2009) The multiplicity of controls and the making of innovation, European Accounting Review, 18(2), pp. 341-369.

Revellino S. and Mouritsen J. (2015) The Performativity of Calculative Practices and the Dynamics of Innovation; Management Accounting Research, Vol. 28, No. September, p. 31-49.

Seyfang, G. and Smith, A., 2007. Grassroots innovations for sustainable development: towards a new research and policy agenda. Environmental Politics, 16 (4), 584-603.

Scott-Cato M. and Hillier J. (2010) How could we study climate-related social innovation? Applying Deleuzean philosophy to Transition Towns; Environmental Politics; Vol. 19, No. 6, November, 869-887

Simons R. A. (1995) Levers of control: How managers use innovative control systems to drive strategic renewal; Boston: Harvard Business School Press.

Widener, S. (2007) An empirical analysis of the levers of control framework, Accounting, Organizations and Society, (32) pp. 757-788.

Zirger, B.J., Maidique, M. (1990), A model of new product development: an empirical test, Management Science, 36:867-883.

\section{Caption of figures:}

Fig. 1: Toll payment process using Telepass

Fig. 2: The evolution of tolling collection: from manual tolling collection to satellite tolling

Fig. 3: The architecture of the Integrated Viability System (IVS)

Fig. 4: IVS application example

Fig. 5a, 5b, 5c: Getting real time information on traffic fluidity in a click

Fig. 6: Death rate on the Autostrade's motorway network during the period 2000-2016 
